\title{
British Medicine and its Past at Queen Victoria's Jubilees and the 1900 Centennial
}

\author{
MICHAEL WORBOYS*
}

\begin{abstract}
Introduction
Between 1887 and 1901 the Victorian medical élite was drawn into a series of reflections on its profession and recent history. These were prompted successively by: Queen Victoria's Golden Jubilee in 1887, her Diamond Jubilee in 1897, and the turn of the century which was celebrated both at the end of 1899 and 1900, plus Victoria's death in January 1901. The responses of individuals and institutions to these moments provide the opportunity to explore the ideals and identities of the profession at what both contemporaries and historians have seen as a pivotal moment in medical history. ${ }^{1}$ In using public commemorations to explore fin-de-siècle medicine, I am following an approach that has been used by cultural historians to explore social identities, values and ideals. ${ }^{2}$ Historians of medicine have also begun to use "memory" and the construction of historical narratives to reveal the character of professional ideals. For example, John Harley Warner has discussed the different accounts of Paris medicine developed by American and British practitioners in the nineteenth century and the uses to which these were put. ${ }^{3}$ George Weisz has shown how the many "inventions" of Laënnec were used internally and externally by Parisian medical élites to reflect and shape their professional identity. ${ }^{4}$ However, rather than considering topics chosen by members of the profession and used internally, I am discussing the histories and commentaries that were prompted by, and fed into, wider public events. Thus, the centenary commemoration of Jennerian vaccination in 1896, which falls within my period and was marked with special

* Michael Worboys, PhD, Department of History, Sheffield Hallam University, Collegiate Crescent, Sheffield S10 2BP.

I would like to thank John Baxendale, John Pickstone, Matthew Steggle and Keir Waddington for their help in the preparation of this article. I would also like to thank the editors and referees of Medical History for their constructive comments.

${ }^{1}$ S E D Shortt, 'Physicians, science and status', Med. Hist., 1983, 27: 51-68; C J Lawrence, " "Incommunicable knowledge": science, technology and the clinical art in Britain, 1850-1910', J. Contemp. Hist., 1985, 20: 503-20. For the discussion of similar issues for the United States, see J H Warner, 'Science in medicine',

Osiris, 1985, 1: 37-58; idem, 'Ideals of science and their discontents in late nineteenth-century American medicine', Isis, 1991, 82: 454-78; idem, 'The fall and rise of professional mystery: epistemology, authority and the emergence of laboratory medicine in nineteenth-century America', in A Cunningham and P Williams (eds), The laboratory revolution in medicine, Cambridge University Press, 1992, pp. 110-41.

${ }^{2} \mathrm{R}$ Samuel and $\mathrm{P}$ Thompson, The myths we live by, London, Verso, 1990; R Samuel, Theatres of memory, London, Verso, 1999.

${ }^{3} \mathrm{~J} \mathrm{H}$ Warner, Against the spirit of system: the French impulse in nineteenth-century American medicine, Princeton University Press, 1998.

${ }^{4} \mathrm{G}$ Weisz, The medical mandarins: the French Academy in the nineteenth and twentieth centuries, Oxford University Press, 1995.
\end{abstract}


meetings and publications, is not part of my story. ${ }^{5}$ This is not to suggest that this event was a purely internal affair, indeed, the leading figures in experimental medicine, buoyed by the recent success of new immune products such as antisera, antitoxins and bacterial vaccines, used the occasion to attack anti-vivisectionists and promote laboratory medicine. Rather, by concentrating on public commemorations I hope to show the complexity of the identity and ideals of the late-nineteenth-century medical profession, and to better contextualize the emphasis that historians have placed on science and its meanings at the end of the nineteenth century. ${ }^{6}$ In addition, I show how doctors and lay supporters of medical institutions used commemorative events for specific ends, for example, to found new and extend old hospitals, and the establishment of public honours for medical men. ${ }^{\text {? }}$

The doctors who took the lead in these fin-de-siècle events were not only creating self-justifying rhetoric and running reform campaigns, they were also producing the first general histories of Victorian medicine. These histories, by necessity, had to depart from the usual late-nineteenth-century modalities of biographies of great men or anniversary accounts of institutions. ${ }^{8}$ In creating histories of an age, two contemporary historiographic traditions were utilized; the first was idealism, hence the concentration on medical epistemologies and ideas, and the second was the Whiggish tendency to identify the Victorian era with material progress, humanitarian reform, and the spread of civilized values. These medical histories, like all others, can tell as much about the times in which they were written as the times and events they are about. The sampling of each observance shows that rhetoric and actions were adapted to quite immediate circumstances and different audiences, as well as reflecting long running themes. Thus, the limited and low key events at the end of the century, in contrast to the optimism of the 1897 Golden Jubilee, strongly reflected the current state of the South African War. This is a warning to cultural historians of medicine that they should always consider the rhetoric of medicine's Victorian spin-doctors in their specific contexts and be wary of characterizing professional identities and ideals from widely drawn sources.

\footnotetext{
5 'Jenner centennial edition', Br. med. J., 1896, i: $1745-307$.

${ }^{6}$ Victoria's Golden Jubilee in 1887 came at the end of the period covered by Peterson's influential study of the mid-Victorian profession (1858-86) and the year after the consolidating Medical Act Amendment Act of 1886. Many of the themes I consider are also discussed in $\mathbf{M} \mathbf{J}$ Peterson, The medical profession in mid-Victorian London, Berkeley, University of California Press, 1978; R $\mathrm{D}$ French, Antivivisection and medical science in Victorian society, Princeton University Press, 1975.

${ }^{7}$ The nearest parallel to my work is Frank Turner's discussion of "public science", which he defined as "the body of rhetoric" produced by
}

scientists to "justify their activities to the political powers and other social institutions upon whose goodwill, patronage and co-operation they depend". However, Turner is considering an endeavour that was novel to science and looks at a forty-year period rather than specific events. Of course, the management of public relations was not new to medical practitioners, who had always had a public profile in civil society and the state. F M Turner, 'Public Science in Britain, 1880-1919', Isis, 1980, 71: 589-608.

${ }^{8} \mathrm{G}$ Brieger, 'The historiography of medicine', in W F Bynum and R Porter, (eds), Companion encyclopaedia of the history of medicine, 2 vols, London, Routledge, 1992, vol. 1, pp. 24-44. 


\section{The Golden Jubilee, 1887}

At the centre of the celebrations of Victoria's Golden Jubilee was a service of thanksgiving at Westminster Abbey on 24 June. The Queen travelled to the ceremony in a procession with her European relatives, British dignitaries, and soldiers in full ceremonial dress, along streets decorated with flags and garlands. The service was followed by gun salutes, bell ringing, celebration dinners, and fêtes. The scale and pomp of the event was unique, and historians now agree that 1887 saw the beginning of the invention of modern royal celebrations. ${ }^{9}$ The success of the event was in doubt until quite late in the day, as the participation of the Queen was uncertain and the exact form of the main event proved difficult to settle, not least because agitation about Home Rule for Ireland made security an issue. The Queen still maintained the reclusive lifestyle she had adopted on Prince Albert's death in 1861, and most of her public appearances had been functional rather than ceremonial. To the annoyance of politicians, she rarely opened Parliament, preferring to attend events associated with philanthropy, especially hospitals. For example, the Queen regularly stopped off to visit sick soldiers at the army hospital at Netley on her way to Osborne House on the Isle of Wight, and in 1871, she opened the new St Thomas's Hospital. Royal interest in hospitals and medicine had increased after the recovery of the Prince of Wales from typhoid fever in 1871, and he and his wife became regular supporters of the London Hospital, St Bartholomew's and eventually Guy's Hospital. ${ }^{10}$ Such associations and the commercial exploitation of the Jubilee began to change the face of the British monarchy, raising its public esteem and visibility. ${ }^{11}$

The first indication of medical awareness of the Jubilee came in the autumn of 1886 in suggestions from many voluntary hospital boards that the event be marked by fund-raising initiatives. ${ }^{12}$ Such ideas followed the wider sentiment that a Jubilee deserved a permanent public monument, or "good works". ${ }^{13}$ Many hospital boards used the Jubilee to start appeals for new buildings and extensions. In London, the only appeal for a new institution, the Queen's Jubilee Hospital, was opposed by most metropolitan consultants because it would divert contributions from existing hospitals and promised to be another unwanted specialist institution. ${ }^{14}$ The main national appeal was through the Women's Jubilee Fund, which aimed to put a large

\footnotetext{
${ }^{9} \mathrm{D}$ Cannadine, 'The context, performance and meaning of ritual: the British monarchy and the "Invention of Tradition", c. 1820-1977', in E J Hobsbawm and T O Ranger (eds), The invention of tradition, Cambridge University Press, 1983, pp. 101-64. J L Lant, Insubstantial pageant: ceremony and confusion at Queen Victoria's court, London, Hamish Hamilton, 1979; [Jeremy Maas], 'This Brilliant Year': Queen Victoria's Jubilee, 1887, London, Royal Academy of Arts, 1977.

${ }^{10}$ On London hospitals, see G Rivett, The development of the London hospital system, 1823-1982, London, King Edward's Hospital Fund for London, 1986, pp. 94-132.

${ }^{11} \mathrm{~T}$ Richards, "The image of Victoria in the year of Jubilee', Victorian Studies, 1987, 31: 1-32.
}

${ }^{12} \mathrm{Br}$. med. J., 1886, ii: 1061, 1181.

${ }^{13}$ See Lancet, 1887, i: 348, 400, 501, 654, 753. There were many local events, as in Manchester, where "a National Exhibition of Arts, Science and Industry" was created on thirty-three acres at Old Trafford, though this found no place for medicine. The exhibition's nine sections were: Industrial Design, Silk Industry; Chemical and collateral Industries; Photography; Old Manchester and Salford; Music; Electric Lighting and Horticulture; an Irish Section; and Fine Arts. 'This Brilliant Year', op. cit., note 8 above, p. 72.

${ }^{14}$ Lancet, 1887, i: 237, 290. 


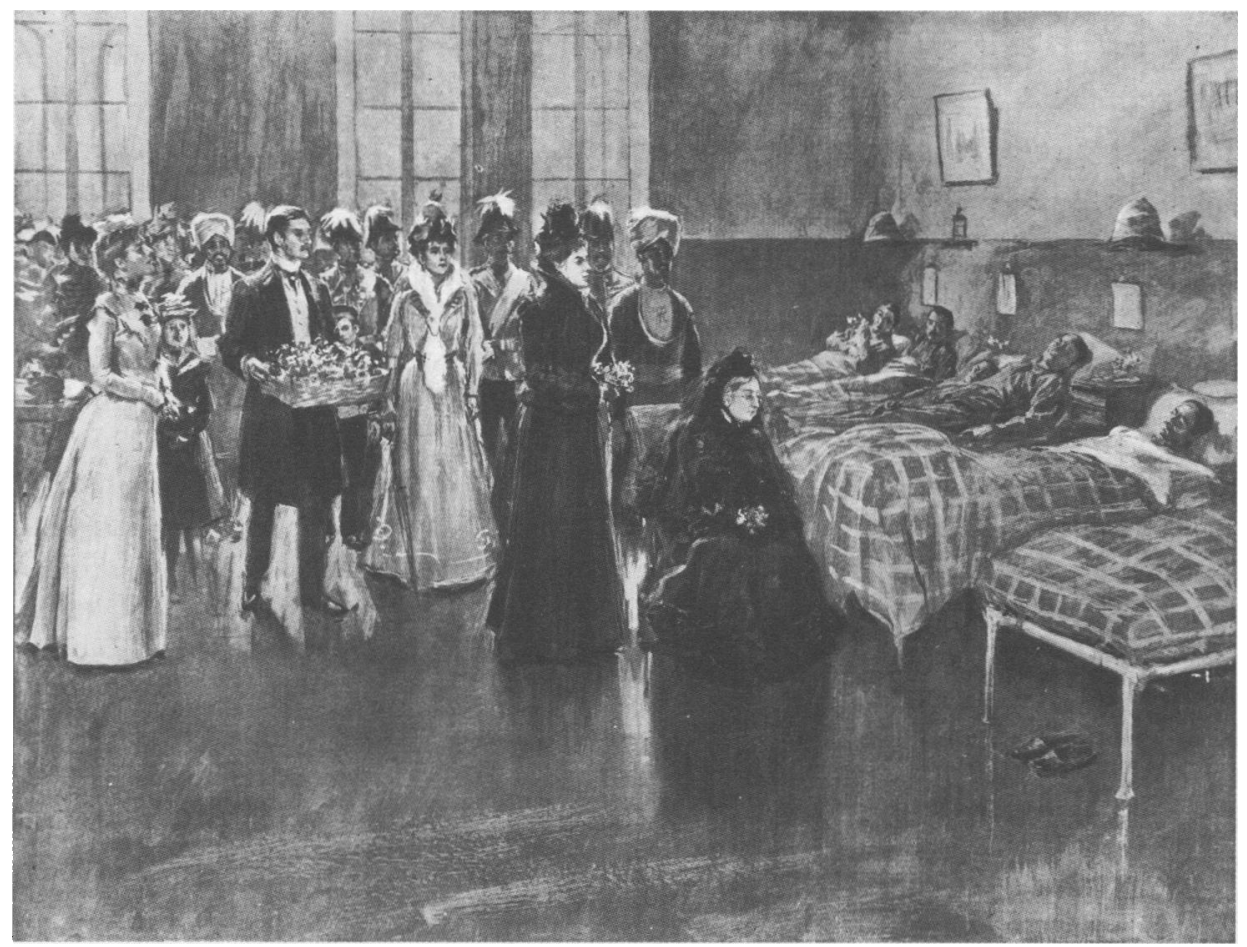

Figure 1: The Queen and the wounded, c. 1900: "Her Majesty visiting a ward in Netley Hospital”. Process print after R C Dickinson after W Hatherell (Wellcome Library, London).

sum at the Queen's disposal for whatever she felt most fitting. Many interest groups vied for the Queen's favour, with the medical profession and the supporters of voluntary hospitals among the most vocal, being encouraged by rumours that the Queen favoured devoting the Fund to charitable purposes.

The Jubilee came at an opportune moment for Henry C Burdett, who at the turn of the year had launched both the Hospitals Association and a weekly publication The Hospital. ${ }^{15}$ The aim of both was to help rationalize the hospital system, especially in London, and to improve finances. Hence, it is unsurprising to find Burdett involved in the creation of a Special Committee of the Hospital Sunday Fund to exploit the Jubilee to raise money to support the revenue costs for London voluntary hospitals. ${ }^{16}$ The Hospital Sunday Fund was the main source of casual donations to metropolitan institutions, through collections organized at special church services in June each year. In the mid-1880s, the Fund provided approximately four times the revenue of the Hospital Saturday Fund, which collected from workmen on pay-day. ${ }^{17}$ The initial hope of the Special Committee was that $£ 1$ million could be raised in Jubilee Year, which would be used to offset the annual combined deficits of metropolitan

${ }^{15}$ The Times, 21 January 1887 , p. $6 \mathrm{c}$.

${ }^{16}$ Lancet, 1887, i: 140, 235.

\footnotetext{
${ }^{17}$ In 1886 the Hospital Saturday Fund
} collected $£ 10,000$, the Sunday Fund $£ 40,000$. 
voluntary hospitals, then estimated to be $£ 100,000$ per annum. ${ }^{18}$ While the appeal would benefit the medical profession, securing more appointments at prestigious institutions, it was presented as an opportunity for the public to contribute to great humanitarian ventures. These sentiments were captured in the Jubilee poem, published by the Poet Laureate, Alfred Lord Tennyson, in April 1887. The sixth stanza read as follows,

You that wanton in affluence

Spare not now to be bountiful.

Call your poor to regale with you;

Make their neighbourhood healthfuller:

Give your gold to the hospitals;

Let the weary be comforted;

Let the needy be banqueted;

Let the maimed in his heart rejoice

At this year of her Jubilee! $!^{19}$

In the week before the Jubilee celebration, an editorial in the Lancet, with hyperbole on full throttle, invoked both God and Thomas Guy to advance the same point:

The very note of the Messiahship was that the sick were healed, the lame made to walk, and the blind to see. Such services are rendered every day in London Hospitals. As far as the services are medical, they are mainly gratuitous. All that the public and the churches are asked to do is to find beds and maintenance and surgical instruments, while the beneficent work of medicine is being done.... Of all the uses of wealth none is better than the support of institutions for the mitigation of pain and disease. If we cannot all do as much as GUY did, we can all do work of the same kind; and in doing it we shall do much to hold society together and to make the poor feel thankful to GOD for the existence of the rich. ${ }^{20}$

The medical profession was aligning itself with religious, philanthropic and altruistic sentiments, highlighting its service ethic and the paternalism of a gentlemanly profession. Somewhat paradoxically, the once radical Lancet was allying the medical profession with One-Nation Tories.

Burdett's hope of creating a $£ 1$ million fund was abandoned months before the Jubilee, not least because no large donations were forthcoming. Moreover, there were no signals from the Queen that hospitals would be favoured from her Fund. That neither the name of the Queen, nor the idea of a Jubilee commemoration, was enough to inspire donations, confirms the view that before the Jubilee the monarchy did not excite public opinion, let alone have the influence to pull in charitable

\footnotetext{
${ }^{18}$ The Times, 25 March, 1887, p. 14b.

${ }^{19}$ First published as 'Carmen sæculare. An ode in honour of the Jubilee' in Macmillan's Magazine, April 1887. In 1889 Tennyson revised the poem and added new lines and word changes that are shown in bold below: "You that wanton in affluence/Spare not now to be bountiful./Call your poor to regale with you;/All the lowly, the destitute/Make their neighbourhood healthfuller:/ Give your gold to the hospitals;/Let the weary be
}

comforted;/Let the needy be banqueted;/Let the maimed in his heart rejoice/At this glad ceremonial/And this year of her Jubilee!", C Ricks (ed.), The poems of Tennyson in three volumes, Harlow, Longman, 1987, vol. 3, pp. 159-62.

${ }^{20}$ Lancet, $1887, \mathrm{i}: 1240$. An editorial the previous week had stated that the "hospital" was an institution devised by "the human mind in its divine moods" and was "the very crown of charities". Ibid., 1193. 


\section{Michael Worboys}

donations. Thus, what had started as a positive measure to make voluntary hospitals solvent, quickly became a defensive enterprise to protect hospital donations from the competing claims of other Jubilee charities, not to mention parties, frivolous novelties and mementoes. To protect its position, the Hospital Sunday Fund Special Committee strove to raise the profile of its traditional Hospital Week in June, which in 1887 worryingly fell the weekend before the Jubilee. Meetings were arranged across London with high profile speakers such as the Prime Minister, the Archbishop of Canterbury, the Lord Mayor, Cardinal Manning, Henry Irving, and Sir Andrew Clark. ${ }^{21}$ One of Burdett's additional aims was to voice concern about the calls to place the whole hospital system under "a department of the State". The argument against the proposal being that such an organization would be inefficient and would deny the public opportunities for Christian "giving", which was said to be a far more pleasurable activity than the "cold and unsympathetic" business of paying rates. Roughly the same sum was collected on Golden Jubilee Hospital Sunday as in the previous year. ${ }^{22}$ The best gloss that could be put on this situation was that the Fund's income had been protected; however, there was no hiding the fact that the result was disappointing and seemed to confirm the fears of hospital governors that the limits of public giving had been reached. In the inquest that followed, governors and doctors worried that from the public's point of view there was no correlation between individual giving and public service provision. Indeed, it seemed that the more hospitals received, the more they needed as services and demand grew. Governors were aware that already patients were being asked to pay for services previously supported by the Hospital Sunday Fund, for example, surgical appliances.

The calls for monies from the Women's Jubilee Fund to be given to hospitals went unheeded. The Queen herself was mainly interested in using the money to erect a statue of Prince Albert at Windsor and in acquiring a diamond souvenir. Allocation of the Fund was passed to a small committee that included Sir James Paget, the distinguished surgeon and pathologist. ${ }^{23}$ The committee offered Victoria three choices, with a strong steer to establish an Institute to support the provision of nurses for the sick poor in their homes. The Queen took the advice. ${ }^{24}$ In time, the so-called Queen's Institute helped create modern district nursing in Britain, and had a wider impact on nurse training. ${ }^{25}$ The extent to which the decision to give money to health care beyond hospitals was a snub to the hospitals and the medical profession more widely is unclear. London hospitals were left with their problems and it was possible that the new district nurses would further erode the position of the overcrowded

${ }^{21}$ Lancet, 1887 , i: $1202 ; 1256-8 ; 1301-2$.

Meetings were held in Lambeth Palace, the Mansion House, the People's Palace and various vestry and town halls.

${ }^{22}$ Lancet, 1887, ii: 122.

${ }^{23}$ The others members of the Committee were the Duke of Westminster and Sir Rutherford Alcock. Alcock had clashed with Burdett earlier in the year over the extent of the funding problem of London hospitals. The Times, 19 March 1887, p. 12b; 25 March 1887, p. 14b.
${ }^{24} \mathrm{Br}$. med. J., 1888 , i: 88,96 . Once support for hospitals was lost, Burdett lobbied to have all or part of the sum donated as the start up capital of his Nurses Pension Fund. C J Maggs, $A$ century of change: the story of the Royal National Pension Fund for Nurses, London, Royal National Pension Fund for Nurses, 1987.

${ }^{25}$ M E Baly, A history of the Queen's Nursing Institute, 1887-1987, London, Croom Helm, 1987. 


\section{British Medicine and its Past}

ranks of general practitioners. However, the initial impact of the Institute was small because its resources were modest and it took many years to establish. ${ }^{26}$

The medical élite was also disappointed by the Jubilee honours list in June, which they hoped would at last signal official recognition of the new status of the profession. In 1886 Richard Quain had renewed the profession's long campaign for honours calling for a new Order of Medical Merit, which Punch ridiculed with suggestions for titles such as the "Marquis of Magnesia" and "Baron Bluepill" ${ }^{27}$ The Jubilee list contained the usual coterie of court physicians and surgeons, doctors who had served in the armed forces, and those who had served the state, most notably John Simon. ${ }^{28}$ The Queen herself had blocked the expected elevation of her leading personal physician, William Jenner, saying that since 1872 "He has done nothing remarkable" ${ }^{29}$ The Dublin-based Medical Press was angered at the absence of awards for Irish and Scottish practitioners, sentiments which drew on the nationalist political context of the whole event. Elsewhere, there were suggestions that the time had come for distinguished medical men to have a special honour, something like the légion d'honneur in France. ${ }^{30}$ An additional insult was that, as previously, only knighthoods were awarded and calls for a medical peerage continued to be ignored in government. In 1887, the area most expected to receive recognition was sanitary science, thus it was thought particularly sardonic that John Simon was made a "Knight of the Order of the Bath". 31

There were surprisingly few retrospectives of medicine and surgery published for the 1887 Jubilee. In a short commemorative editorial, the Lancet celebrated the old rather than the new, maintaining that comparative and morbid anatomy had been, and continued to be, the basis for all the advances of the Victorian era. $\mathrm{Hu}$ manitarianism and science were often linked, especially around the idea that greater scientific precision had informed the sanitary improvements that had led to the falls in mortality, and had allowed doctors to be more compassionate, through anaesthesia, hygiene and moderate therapies. Doctors used the established tactic of calculating the number of lives saved by comparing mortality levels in the 1830 s with those in the $1880 \mathrm{~s}$. The figures were said to show that sanitary science had saved over 500,000 lives in the past half century, with the annual number in the late 1880 s at around 50,000..$^{32}$ Richard Thorne Thorne, then head of the Medical Department of the Local Government Board and Simon's successor, wrote a review of "the progress of preventive medicine". ${ }^{33} \mathrm{He}$ too was sanguine about improvements, though he

\footnotetext{
${ }^{26}$ Baly, op. cit., note 25 above, passim; $\mathrm{S}$ Dixon, 'The archive of the Queen's Nursing Institute', Med. Hist., 2000, 44, 251-66.

${ }^{27}$ Lancet, 1886, i: 267-8, 308-9; cf. Punch, 1886, 90: 78 .

${ }^{28}$ Lancet, 1887 , i: 1301.

${ }^{29}$ Lant, op. cit., note 9 above, p. 198. The Prime Minister, Lord Salisbury, had proposed William Jenner to appease medical pressure for a significant award.

${ }^{30}$ Medical Press, 1887, i: 620-1; ii: 39.

Editorials in the press spoke of the profession's

"humiliation", suggesting that expectations of
}

more and higher rewards had been built up in the months before the Jubilee.

${ }^{31} \mathbf{R}$ Brudenell Carter, 'Medicine and surgery', in $\mathrm{T} \mathrm{H}$ Ward, The reign of Queen Victoria, London, Smith, Elder and Co., 1887, pp. 388-444, on p. 443. See also 'The progress of sanitary science', Lancet, 1887 , ii: 25-6.

${ }^{32}$ Carter, op. cit., note 31 above, p. 390.

${ }^{33} \mathrm{R}$ Thorne Thorne, On the progress of preventive medicine during the Victorian period, London, Shaw and Sons, 1888. 


\section{Michael Worboys}

worried in Malthusian vein that the extra lives saved were contributing to poverty and suffering. That said, he was less concerned with general trends than with showing how the improvements had been based on sound epidemiological understanding and that different disease problems required different approaches. Thus, the decline in the incidence of smallpox was portrayed entirely as a triumph for vaccination and the rigorous application of legislation. He claimed that the incidence of typhoid fever and cholera had been reduced by greater cleanliness and sanitary engineering, while the decline in consumption was due to soil drainage. Thorne was no enthusiast for bacteriology, though he looked to the new science of germs to provide answers for two disease problems with which there had been little or no progress-scarlatina and diphtheria.

The most extended discussion of medicine during Victoria's reign to 1887 was written by Robert Brudenell Carter and published in Thomas Humphry Ward's celebratory The reign of Queen Victoria. This two volume edited work included essays by leading authorities of the day, including $\mathrm{T} \mathrm{H}$ Huxley on 'Science' and Matthew Arnold on 'Schools'. In 1887, Carter was Consulting Ophthalmic Surgeon at St George's, but owed his invitation to contribute to his journalistic work. During service in the Crimean War he had befriended W H Russell and subsequently became a regular contributor to The Times, and then the Lancet. ${ }^{34}$ Indeed, his obituarists argued that he was able to use The Times as a vehicle for the views of the Wakleys and the Lancet from the late 1860s to the 1890s. Carter chose to concentrate on "the application of science to the arts of restoring health and promoting longevity". $\mathrm{He}$ too emphasized the progress in preventive as opposed to curative medicine, making the key change over the previous fifty years the new understanding of the causes and processes of disease. He argued that this had first brought benefits in preventive practice with the abandonment of fatalism and religious explanations of disease in favour of naturalistic approaches and specific etiologies. Then, sanitary science had delivered methods, such as vaccination, isolation, and water purification, to be deployed against different diseases. Carter celebrated the achievements of Pasteur and others in identifying the bacteria responsible for many infectious diseases. However, he was sceptical of the germ theory of disease, which he identified exclusively with septic conditions and antiseptic surgery; like many contemporaries, he maintained a chemical model of tissue breakdown and alkaloid poisoning that was best combated by cleanliness. ${ }^{35} \mathrm{He}$ suggested, with it has to be said few examples, that clinical medicine had also been revolutionized by improvements in pathological anatomy and physiology. The benefits of exact methods were exemplified in diagnosis by the stethoscope, the thermometer and the differentiation of specific conditions, and in treatment under anaesthesia, which allowed surgeons to work conservatively with more precision, and physicians to control pain. As might be expected, he expounded at length on operative surgery, using as examples ovariotomy, neurology

${ }^{34} \mathrm{Br}$. med. J., 1918, ii: 502-3; Lancet, 1918, ii: 607; R Brudenell Carter, Doctors and their work,

${ }^{35}$ Carter, op. cit., note 31 above, pp. 428-31. or, medicine, quackery and disease, London, Smith, Elder and Co., 1903. 
and, of course, ophthalmology, but he also deemed local anaesthetics and cleanliness to be more important than chloroform and carbolic acid.

Carter was very chauvinistic and insular. His assessment was that the contribution of "England and her people" (note he found no place for the Welsh, Scots and Irish) to "the advancement of medical science has been greater, not only than that of any other country, but than that of all other countries put together" ${ }^{36} \mathrm{He}$ went on to say that in "preventive medicine we stand alone" and that the English innovations of surgical cleanliness and ovariotomy outweighed all other clinical developments of the previous fifty years. However, he conceded anaesthesia to America, the stethoscope to France, and, "by an unhappy accident", the ophthalmoscope to Germany. English pre-eminence, moreover, had been achieved without government support or recognition of research, despite "silly legislation" over vivisection and in the face of popular resistance due to sentiment and ignorance. Finally, medical reform and improved education had ensured that medical men (Carter expected medical women would find the competition at home too tough and would discover their vocation in India) had the widest knowledge of their calling, the qualities of "tenderness and humanity", and a service ethos that meant they shrank from "no hardships, no fatigues and no dangers which the perils of others may require them to encounter". ${ }^{37}$

The only other extended reflection on 'Medicine under Queen Victoria' was published by Benjamin Ward Richardson in his journal Asclepiad. ${ }^{38}$ In the 1850s and 1860s, Richardson was a leading innovator in physiological chemistry, but by the 1880s he had become somewhat of a maverick figure, known particularly for his old-style sanitarian views and opposition to bacteriology. ${ }^{39}$ Richardson also expounded on the themes of humanity and science, choosing six areas that strongly reflected his own interests: (i) moral therapy in the treatment of the insane; (ii) the lives saved by preventive medicine; (iii) the humaneness of anaesthesia; (iv) the decline of heroic therapies and their replacement with physiologically-based chemical remedies; (v) the cures introduced by abdominal surgeons, based on surgical skill, hygiene and after-care, but not antisepsis; and finally, (vi) more accurate diagnoses. Richardson followed his history with a brief biography of his old friend John Snow, who was portrayed as "one of the most faithful representatives of his profession in his day and generation". ${ }^{40} \mathrm{He}$ had come from humble stock but had risen, Samuel Smiles fashion, by education and effort to be a respected practitioner and investigator. He was a pioneer of anaesthesia and had most famously administered chloroform to Queen Victoria in two of her confinements in the 1850s. It was also his investigations of the water from the Broad Street pump, neglected in his own day, that were later seen as crucial in showing that cholera was a water-borne disease. However, more

\footnotetext{
${ }^{36}$ Ibid., p. 441.

${ }^{37}$ Ibid., p. 444.

${ }^{38}$ B Ward Richardson, 'Medicine under Queen Victoria: an epitome of the great advancements in practical medicine, preventive and curative, by the Victorian faculty of physic throughout the Empire', Asclepiad, 1887, 4: 201-73.
}

\footnotetext{
${ }^{39}$ L G Stevenson, 'Science down the drain: on the hostility of certain sanitarians to animal experimentation, bacteriology and immunology', Bull. Hist. Med., 1955, 29: 1-26.

${ }^{40}$ Richardson, op. cit., note 38 above, p. 202.
} 


\section{Michael Worboys}

significant for Richardson, was the portrayal of Snow as an "ideal doctor", a man who worked selflessly, never acquiring substantial wealth, who devoted himself to public service and patient care.

\section{The Diamond Jubilee, 1897}

The Jubilee celebrations in 1897 were better planned and executed than those a decade earlier. They had greater pomp and spectacle, and were an imperial rather than a British event. Preparations had begun in 1896 and a Diamond Jubilee Committee orchestrated the whole event from January $1897 .{ }^{41}$ Again, many hospitals tried to use the occasion to develop their facilities, but no one was better prepared than Henry Burdett, who tried once more to improve the funding of London's voluntary hospitals. Since 1887 , he had been cultivating the patronage of the Prince and Princess of Wales, even publishing a sycophantic account of their charitable work in $1889 .{ }^{42}$ In 1896, he persuaded the Prince of Wales to become Vice President of the Hospital Sunday Fund and in January 1897 launched the Prince of Wales Hospital Fund. ${ }^{43}$ With this Fund, as in 1887 , Burdett wanted to raise a capital sum to generate investment income, while also drawing in new regular subscribers. ${ }^{44}$ The scheme did not have the wholehearted support of the metropolitan medical élite, many of whom believed the first priority was to create a Central Hospital Board for London to rationalize existing provision and funding. However, with the backing of the Queen, the scheme continued, raising $£ 227,000$ by the end of the year. This did not match expectations and the structure of the Fund meant that most money went into investments, allowing only $£ 22,000$ to be distributed in the first year. ${ }^{45}$ None the less, the promise of continued royal endorsement augured well for the profession, especially as hospitals were becoming more important to it, functionally and ideologically. ${ }^{46}$ However, many smaller ventures struggled. For example, it took so long to collect funds for the planned Jubilee convalescent home for the Brompton Hospital that the scheme was eventually merged with subscriptions for the hospital's sanatorium which opened in $1904 .^{47}$ While most hospital supporters and doctors welcomed any improvements in funding, there was some dissent. One correspondent to the British Medical Journal complained that every new ward, extension or cottage

\footnotetext{
${ }^{41}$ Lant, op. cit., note 9 above, pp. 215-46.

${ }^{42} \mathrm{H}$ C Burdett, Prince, princess, and people: an account of the social progress and development of our own times, as illustrated by the public life and work of their Royal Highnesses the Prince and Princess of Wales, 1863-1889, London, Longmans, Green, 1889.

${ }^{43}$ Lancet, 1897, i: 192. F K Prochaska, Philanthropy and the hospitals of London: The King's Fund, 1897-1900, Oxford, Clarendon Press, 1992; idem, Royal bounty: the making of a welfare monarchy, New Haven, CT, Yale University Press, 1995.

${ }^{44} \mathrm{~K}$ Waddington, 'Finance, philanthropy and the hospital: metropolitan hospitals, 1850-1898',
}

\author{
Unpublished PhD Thesis, University College \\ London, 1995, pp. 314-21. \\ ${ }^{45} \mathrm{Br}$. med. J., 1897, ii: 1863 . The plan had \\ been to raise a capital sum of $£ 1$ million, to yield \\ $£ 40,000$ per annum from interest, and to raise an \\ annual income of $£ 60,000$ from new donors. \\ ${ }^{46} \mathrm{C}$ Lawrence, Medicine in the making of \\ modern Britain, 1700-1920, London, Routledge, \\ 1994, pp. 55-84. \\ ${ }^{47} \mathrm{~J}$ R Bignall, Frimley: the biography of a \\ sanatorium, London, National Heart and Chest \\ Hospital Brompton Hospital, 1979, pp. 15-19.
}


hospital meant more unpaid work for doctors; his solution was that more effort should be put into providing revenue for hospitals and that the pay of junior hospital doctors should be increased. ${ }^{48}$

Diamond Jubilee year had begun well for the medical profession. In the New Year's honours list Sir Joseph Lister was made Lord Lister-medicine's first peerage. ${ }^{49}$ As well as a deserved personal reward, the honour was interpreted in editorials as long overdue recognition of the improved social and cultural position of medicine, though questions were asked in published correspondence about how long it would be before Lister was joined by another medical man. ${ }^{50}$ The choice of Lister was significant, for though he was known as a pioneer of antiseptic surgery-a clinical innovation - he was by this time an elder statesman of the profession and a vocal supporter of laboratory medicine and medical research. Indeed, a major feature of the medical celebrations in 1897, especially when compared with those a decade earlier, was the emphasis given to how "medicine has been metamorphosed from an art into a science". ${ }^{51}$ Doctors spoke and wrote less about their humanity and service to the public, and more about how science had transformed their work. ${ }^{52}$ The general benefits of science were seen in the two great innovations of the age: anaesthesia and antisepsis, while the more recent advances from the laboratory were exemplified by vaccines, $\mathrm{X}$-rays, and serum therapy, representing prevention, diagnosis, and treatment. ${ }^{53}$ Serum therapy in particular was trumpeted as signalling the arrival of "scientific therapeutics", enabling physicians to match the ability of surgeons to intervene and remove the causes of disease. ${ }^{54}$ Such successes had made the profession more willing to take on anti-vivisectionists more directly. ${ }^{55}$ In May 1897, the Prince of Wales opened the new laboratories at Guy's Hospital, an event that was reported in the medical press as tacit royal approval for experimental medicine. ${ }^{56}$ There were also reports that anti-vivisection sentiment was waning; for example, an antivivisection meeting in Poplar in May ended in "disorderly scenes" when a resolution criticizing purported experimentation in local hospitals was defeated. ${ }^{57}$ None the less, the previous influence of anti-vivisectionists was repeatedly said to have limited Britain's achievements in medical and surgical science when compared to Continental countries, many of which also provided state funding for research. Thus, the picture painted of British medicine since 1837 was of heroic individuals making practical

${ }^{48} \mathrm{Br}$. med. J., 1897, i: $1110,1195$.

${ }^{49} \mathrm{G} \mathrm{T}$ Wrench, Lord Lister: his life and work, London, T Fisher Unwin, 1913, pp. 340-1.

${ }^{50} \mathrm{Br}$. med. J., 1897, i: 93.

${ }^{51}$ Lancet, 1897, i: 1687.

${ }^{52} \mathrm{H}$ Baptist Crofts, 'Victorian science: its status and development', Westminster Rev., 1897, 148: 569-74.

${ }^{53} \mathrm{M}$ Morris, 'The progress of medicine in the Victorian era', Nineteenth Century, 1897, 41: 739-58.

${ }^{54}$ Practitioner, 1897, 58: 591.

${ }^{55}$ Br. med. J., 1897, i: 1576-7.

${ }^{56}$ Br. med. J., 1897, i: 1373,1434 . For a full report of the speeches see: Nature, 1897, 56:

105-6. Endorsement by the Prince of Wales may have been a mixed blessing, as, like his Teutonic father, he was often criticized for his hunting, though the clamour to engage royal patronage suggests that this time it was well worth having.

${ }^{57}$ Br. med. J., 1897, i: 1328 . The early months of 1897 saw some agitation on the question of the abuse of patients in hospitals. A journal called Church Bells reported the activities of the Society for the Protection of Hospital Patients. Ibid., pp. $485,598,1110,1431-2$. Poplar was the Parliamentary seat of Sydney Buxton who had introduced a Bill in 1892 to allow local authorities to subscribe to voluntary hospitals. 


\section{Michael Worboys}

innovations rather than scientific discoveries, often against the odds. The great shifts in understanding - localized pathology, cellular pathology and bacterial etiology-were conceded to France and Germany, but every first rank advance in the "art of medicine" was claimed for Britain. ${ }^{58}$ The "captain jewels in the carcanet" were vaccination (Edward Jenner), chloroform anaesthesia (James Young Simpson), antiseptic surgery (Joseph Lister), and sanitary science (John Snow, Edmund Parkes, and John Simon). The picture was of Britain as the "workshop of the medical world", whose citizens on average enjoyed longer lives and better health than those of other European countries, despite their more developed scientific research institutions.

The centrepiece of the Jubilee celebrations was once again a commemorative service in London, only this time the parade was longer and grander. Festivities lasted a full two weeks, with popular enthusiasm encouraged in local bazaars and street parties, as well as services and parades. The Empire was well represented in all aspects of the metropolitan celebrations, with the Queen reviewing colonial troops and hosting a dinner for colonial prime ministers at Windsor in the week after Jubilee Day. The medical profession took up the imperial theme, most obviously when the British Medical Association (BMA) held its first annual meeting overseas in Montreal in September. More generally, the profession adapted their rhetoric to the spirit of the times and debated the future of an imperial rather than a merely national profession. ${ }^{59}$ It was in the wake of the Montreal meeting, at which he too gave a paper, that in the following October Patrick Manson made his plea for special education in tropical diseases. This imperial backdrop no doubt helped to ensure the immediate recognition of Ronald Ross's mosquito-malaria work when it was announced in December $1897 .^{60}$

In its special 140-page 'Queen's Commemorative Number', published on 19 June 1897, the British Medical Journal expounded in an editorial on the theme of the "progress of the medical sciences" with a litany of imperial and military metaphors. It was suggested that while "The expansion of the empire in the last sixty years has been great ... the expansion of the realm of medicine has been immeasurably greater". ${ }^{61}$ The story told was of "the march of modern medicine from conquest to conquest", exploring parts of the body that were "terra incognita in 1837", using ever more "active weapons" to "attack" the "enemy" of disease. ${ }^{62}$ An editorial in The Times reflected that "science had established its dominion in medicine". ${ }^{63}$ The main factors enabling advances were said to be "the application of scientific methods" and the development of "instruments of precision". The greatest step forward was

\footnotetext{
${ }^{58} \mathrm{~W}$ Osler, 'Medicine in greater Britain', $\mathrm{Br}$. med. J., 1897, ii: 578.

59 The event was linked to a meeting of the British Association for the Advancement of Science in Toronto in August. M Worboys, 'Science and social imperialism', in R MacLeod and P M D Collins (eds), The parliament of science: the British Association for the Advancement of Science, 1831-1981, Northwood, Science Reviews Press, 1981, pp. 170-87.
}

\footnotetext{
${ }^{60}$ On "Mosquito Day", 20 August 1897, some 200 British doctors were en route to Montreal to celebrate, so it turned out, the potential of medicine to Empire.

${ }^{61} \mathrm{Br}$. med. J., 1897, i: 1521.

${ }^{62}$ Ibid., pp. $1521,1527$.

${ }^{63}$ The Times, 22 March 1897, p. $11 \mathrm{~d}$.
} 
the "discovery of the causes of many diseases", especially the power of microorganisms, and the ability to work with the protective and defensive mechanisms of the body to remove causes rather than merely to treat symptoms. ${ }^{64}$ On the same day, the special section in the Lancet opened by saying that all medical methods were "now based upon scientific research", and reproduced a portrait of T H Huxley. Yet, somewhat paradoxically, on the facing page was a pastiche of an Ode of Horace, in Latin, with a very brief outline translation as a footnote. ${ }^{65}$ The poem compared doctors to warriors "making diseases turn and flee", and equated modern surgeons with Machaon, the fighting physician in the Iliad, in his productive uses of "violence" in surgical diagnosis and operations.

Past achievements and present work were represented in histories constructed in terms of the progress of the positivist conception of science. The adoption of positivist methods was seen retrospectively to have enabled medicine to utilize other natural sciences, and promised a linear sequence of new facts leading to new applications. First and foremost, celebratory authors argued that more careful and precise observations had allowed knowledge to grow rapidly in quantity and quality, making the accumulation of the last six decades equal to that of several previous centuries. ${ }^{66}$ Time and again reference was made to the precision, completeness and accuracy of modern observations, aided by new technologies such as the microscope, chemical analysis and physical methods imported from physics and chemistry. However, there had also been a change of style, with practitioners becoming shrewder, more painstaking and earnest, which was linked to the decline in metaphysical speculation and the use of the inductive method. ${ }^{67}$ It was significant that little was written about the germ theory of disease, rather doctors and scientists wrote of "bacteriology", a fast maturing discipline with exact methods, an expanding body of knowledge, and, latterly, effective clinical applications. ${ }^{68}$ Bacteriology was associated with the centrality of etiology in modern preventive and curative practice, and the importance of understanding the specificity of causes and the mechanisms of diseases. Now that causes were understood, there was more scope for their direct removal, whereas at the start of the Victorian era knowledge was confined to the results of disease and the mere alteration of symptoms. At this time, bacteriology embraced what came to be known as immunology, though immunological theories were secondary to practices, such as serum diagnosis, vaccine development and antitoxin therapy, which were attracting more attention than laboratory discoveries.

The extent to which medicine had become influenced by experimentalism was celebrated by some and ignored by others. ${ }^{69}$ The supporters of laboratory medicine pointed to the ways scientists had developed subjects like physiology and applied them to pathology, changing the focus of the latter from the results of disease to

\footnotetext{
${ }^{64} \mathrm{Br}$. med. J., 1897, i: 1521-2, 1554.

${ }^{65}$ Lancet, 1897, i: 1686-7. I would like to thank Matthew Steggle (SHU) for help with the translation and interpretation of this poem.

${ }^{66}$ The Times, 22 March 1897, p. 11c-d.

${ }^{67}$ Practitioner, 1897, 58: 620; Lancet, 1897, i: 1691.
}

\footnotetext{
${ }^{68} \mathrm{M}$ Worboys, Spreading germs: disease theories and medical practice in Britain, 1865-1900, Cambridge University Press, 2000.

${ }^{69}$ Lancet, 1897, i: 1687.
} 


\section{Michael Worboys}

processes and then to causes. There was even talk that metaphorically, if not literally, the "microscope and test tube" had replaced eye, ear and hand at the bedside. ${ }^{70}$ Anaesthesia, previously described as an empirical, clinical innovation, was now presented as a product of chemical and biological research, which gave the clinician the same type of control of the patient that the laboratory scientist had over animals in physiological experiments. The development of etiological understanding was also linked to medicine's increased scientificity, which in turn had allowed sanitary science to become more refined and targeted, and which, with vaccines and antisera, was aiming to prevent disease by changing the body's internal environment. The contribution of medicine to the fall in mortality levels was again a major feature of Jubilee reflections, for example, a report in The Times estimated that sanitary improvements were now keeping alive 77,000 more people a year compared with $1837 .^{71}$ In therapeutics, the gains came not only from new remedies, but from the recognition that many established drugs had no effect and that moderate therapies were as effective, if not more so, than heavy dosages. Progress in chemistry had made it possible to simplify treatments, allowing only active elements to be given, whilst synthetic drugs were placing pharmacology on a new footing. ${ }^{72}$ Unlike in 1887 , the emergence and development of medical specialisms was celebrated, including the transformation of older subjects such as pathology and therapeutics. ${ }^{73}$

Many of the histories of Victorian medicine were constructed in terms of "now" and "then". Doctors and the public were asked to imagine medical practice without the stethoscope, chloroform, carbolic acid, and antisera, when common diseases were undifferentiated, and when so much was unknown and speculation was rife. However, there was disagreement over when and how the transformation had taken place. In true positivist style, most writers portrayed the changes as evolutionary-the steady accumulation of knowledge, with more facts allowing more exact generalizations and applications to clinical practice. However, a minority argued for revolutions; either in the 1830s and 1840s with localized pathology, or in the 1880s and 1890s with bacteriology. ${ }^{74}$ Both groups observed that British doctors and medical investigators had been world leaders in the first half of Victoria's reign, but had recently been outshone by France and Germany, especially by the schools of Pasteur and Koch. Between the Jubilees, a number of new research and service laboratories had been founded in Britain and the Empire, but they were small and poorly funded compared to those in continental Europe. At one level, this might not have mattered, medicine was after all becoming more international and the diffusion of knowledge and practice more rapid. However, the situation was an affront to a proud national, if not imperial, profession and was also seen to be part of a larger picture of backwardness in science and technology, which fed into and on concerns about Britain's relative economic and industrial position.

While their international standing was perceived to be falling, doctors were

${ }^{70}$ Br. med. J., 1897, i: 1551.

${ }^{71}$ The Times, 19 June 1897, p. 11c. However, an editorial in Public Health was more equivocal, welcoming the fall in the incidence of smallpox, but making more of the relative lack of progress with measles, diphtheria, puerperal fever, and infant mortality. Public Health, 1896-97, 9: 287.

${ }^{72}$ Lancet, 1897 , i: $1688-9$.

${ }^{73}$ Morris, op. cit., note 53 above, p. 754.

${ }^{74}$ Lancet, 1897, i: 1692. 


\section{British Medicine and its Past}

confident that at home they had become more esteemed, and Jubilee editorials painted a glowing picture that ignored the profession's past differences and current divisions. The process of medical reform was said to have been entirely progressive, leading to improved and standardized qualifications. The establishment of regulation was welcomed, as was the closing of the gap between the top and bottom of the profession, which had in turn fostered a more collective spirit. The British Medical Journal, unsurprisingly, maintained that the strength of the BMA, and the burgeoning national, local and subject-based societies were testament to the consolidation of the profession. However, the Lancet dissented, complaining about poor pay and prospects for the majority of doctors in an overcrowded profession, and poor treatment by government. ${ }^{75}$ Typically, all the discussion was of "medical men", with women doctors ignored and the reform of nursing presented simply as providing doctors with reliable ancillary staff. The commemorative issue of the British Medical Journal also made doctors the leading movers and shakers in social reform, in everything from the amelioration in Poor Law conditions to mines legislation; the profession was said in one editorial to always act in "the interests of the whole nation". ${ }^{76}$ The role of doctors in prolonging life and improving conditions extended into the army and navy, where the falls in overall mortality had been greater than in civil society, and to India and other colonies where medical and sanitary advances had been a prerequisite of imperial expansion. ${ }^{77}$

Over 200 British doctors and medical scientists travelled to Montreal for the annual meeting of the BMA in early September. Most scientists also attended the meeting of the British Association for the Advancement of Science (BAAS) in Toronto in August, and almost everyone took the opportunity to travel in North America ${ }^{78}$ Hosting a meeting of a major British professional society was an ambition for the leaders of many colonial cities, as it was thought to endorse their cultural standing as well as being an opportunity to attract immigrants and promote the region economically with Britain. In his presidential address, Dr Roddick, the local organizer, focused mainly on the virtues of Canada as a health resort, though he also speculated that the BMA offered politicians a model of the emerging political idea of "Imperial Federation"-a voluntary association for common goals working for mutual gain. It was left to William Osler, then in Baltimore, to wax lyrical on the imperial theme, which he did in his address on 'Medicine in Greater Britain'. ${ }^{79}$ He claimed that "We English are the modern Greeks, and we alone have colonized as they did, as free people" ${ }^{80}$ His "Greater Britain" included the United States as well as Canada, South Africa, Australia and New Zealand, all of which were developing differently, but still showed "those race qualities which have made us what we are-courage, national integrity, steady good sense, and energy in work". In medicine, these virtues were said to be embodied in the work of Linacre, Sydenham, and Harvey, representing in turn "literature, practice and science". Osler chose Sydenham as the key figure, because his work epitomized scepticism and empiricism.

${ }^{75}$ Lancet, 1897, i: 1701.

${ }^{76} \mathrm{Br}$. med. J, 1897, i: 1571-5, 1664-7.

${ }^{77} \mathrm{Br}$. med. J, 1897, i: 1633-6, 1667-71.
${ }^{78}$ Worboys, op. cit., note 59 above, 174-5.

${ }^{79}$ Osler, op. cit., note 58 above, pp. 576-81.

${ }^{80}$ Ibid., p. 576. 


\section{Michael Worboys}

He ended by celebrating the free, cosmopolitan, meritocratic character of modern medicine and looked forward to a new internationalism in medicine and science, leading perhaps to a wider solidarity in human affairs.

\section{The Centenary}

Opening the October meeting of the Medical Society of London in 1899, Frederick Roberts, then senior physician at University College Hospital, observed that few people in his position could avoid the temptation to reflect on the progress of medicine in the nineteenth century. ${ }^{81}$ In fact, many doctors did resist and there were relatively few reflections on the past and present of medicine around the turn of the century. There were several reasons why centenary musings were so few. One problem was that there was no agreement over when the century ended. Unlike in Germany where the Kaiser decided it would end on 31 December 1899, in Britain there was a laissez-faire approach with celebrations at the end of 1899 and 1900, though the majority settled for 1900 . Also, the South African War preoccupied the press and politicians and cast a shadow over the event. Indeed, fin-de-siècle reflections actually at the turn of the century were generally few, for example, Mike Jay and Michael Neve have drawn on a very wide time period in their collection 1900: a fin-de-siècle reader. ${ }^{82}$ Amongst medical élites there was, perhaps, a feeling that there was nothing new to say after the saturation coverage of "medical progress" in 1897. Also, as noted already, at this time the history of medicine and science was preoccupied with biography and institutional histories, which made the passing of a century unimportant. ${ }^{83}$ Amongst the major medical journals, only the British Medical Journal marked the event with a special publication - a supplement at the end of 1900 entitled 'A century's retrospect', which contained articles on the practice of medicine in 1800 . This made no mention of the nineteenth century as such, though readers were obviously invited to reflect upon "then and now", and the extent of medical progress. ${ }^{84}$ Neither of the comprehensive 'Annus medicus' in the Lancet at the end of 1899 or 1900 made any gesture towards a 'Centennial medicus' ${ }^{85}$ However, the journal signalled the new century with an editorial on 5 January 1901, which made brief remarks about medicine's progress since 1800 and the role the Lancet and its staff had played in medical reform in the last two-thirds of the century. ${ }^{86}$ None of the opening addresses at the medical schools in October 1899 and October 1900 took the end of the century as their explicit theme. Indeed, H G Howse's 'Review of surgery during the past 100 years', delivered to the Royal College of Surgeons of England on 13 December 1899, was prompted by the imminent centenary of the College's Royal Charter.

${ }^{81} \mathrm{~F}$ T Roberts, 'The progress of medicine in the nineteenth century', Lancet, 1899, ii: 995-1000.

${ }^{82} \mathrm{M}$ Jay and M Neve, 1900: a fin-de-siècle reader, Harmondsworth, Penguin, 1999.

${ }^{83}$ The Practitioner continued its regular series of 'Medical Heroes', and kept referring readers back to its Jubilee edition in June 1897.
${ }^{84} \mathrm{Br}$. med. J., 1900, ii: $1833-50$.

${ }^{85}$ Lancet, 1899, ii: 1819-49; 1900, ii: 1882-916.

${ }^{86}$ Lancet, 1901, i: 41-2. The Medical Press carried an editorial on 'The past century' on 5 January 1900 . This had the familiar lineage of medicine progressing through the adoption of science, especially observation and experiment. Medical Press, 1900, i: 14. 


\section{British Medicine and its Past}

All that said, there were some centennial reflections and they were significantly different in tone, if not content, from those two or three years earlier. Unlike the Jubilee writings, which were cast around medical progress and jingoism, the centenary was marked as a more neutral and international event. I am not suggesting that the overall identity and ideals of the profession changed in a short period, only that there was a shift in the issues aired and that this new mood was an adaptation to events, all of which illustrates once again the importance of the immediate present in shaping views of the past. A large part of this change was due to the South African War, not least the impact of "Black Week" in November 1899, and the medical crisis of the summer of 1900 . Indeed, because of the war, the Centennial was barely celebrated as a public event at the end of 1899 or 1900 . General reflections on the economic and political state of the country, or more usually the Empire, were pessimistic. The editorial in the first edition of Nature in January 1901 was on Britain's backwardness in the new electrical and chemical industries and the government's failings in the support of technical education and scientific research ${ }^{87}$ In his famous 'Anticipations', published in the Fortnightly Review in 1901, H G Wells remarked on the absence of serious social and technological forecasts and reflections similar to his own. ${ }^{88}$

In medical reflections, the histories of progress across the board characteristic of the Jubilee were replaced by more thoughtful views. For example, there was greater willingness to consider differences across medicine. John Burdon Sanderson, grand old man of British physiology and pathology, and Regius Professor of Medicine at Oxford, speaking at the Middlesex Hospital in November 1899, was quite clear that during the previous 100 years "the influence of scientific discovery has been much greater in surgery than in medicine". He stated that, especially since 1870 , surgeons had acquired "new powers for the preservation of life and relief of suffering", benefiting from research on anaesthesia, septic diseases (leading to antisepsis), and neurology. ${ }^{89}$ On the other hand, progress in medicine was said to have been largely restricted to diagnosis; nosology remained dominant over pathology, which meant that preventive medicine and therapeutics had not developed as much as they could and should have done. Sanderson, speaking at a hospital that had just opened a major new pathological research laboratory, was explicitly advancing the case for the establishment of research in all medical schools, speaking to government and élite clinicians. ${ }^{90}$ His point was that medical research had lagged too long with inadequate resources and empirical-clinical approaches, and that it now needed large-scale investment in experimental laboratory research.

Many doctors also worried about the return of speculative theorizing and enthusiasms, in no small measure fed by commercial forces. Michael Foster had warned

\footnotetext{
${ }^{87}$ 'The new century', Nature, 1900-1, 63: $221-4$.

${ }^{88}$ H G Wells, 'Anticipations', Fortnightly Rev., 1901, 69: 747.
}

\footnotetext{
${ }^{89} \mathrm{~J}$ B Sanderson, 'The relation of science to experience in medicine', Br. med. J., 1899, ii: 1333.

${ }^{90}$ Michael Foster also repeatedly made the same point. Practitioner, 1901, 66: 122-4.
} 


\section{Michael Worboys}

in 1897 that the "new alchemy which makes gold out of serum is an ignoble business, and degrades those who pursue it below the level of the vulgar quacksalver". ${ }^{1}$ However, Frederick Roberts, an old style clinician, welcomed specific therapies and had high hopes for new hygienic remedies, exemplified by the sanatorium treatment being promoted by the anti-tuberculosis movement. ${ }^{92}$ Indeed, prevention and therapy were linked in so-called hygienic regimes, which aimed to strengthen the constitution so that bodies could combat existing diseases and ward off future problems. ${ }^{93}$ This was seen explicitly with infectious diseases, where there was a greater emphasis on improving the human "soil" in which diseases developed, rather than on preventing the spread of the "seeds" of infection. This view was illustrated in the first editorial in the Lancet of 1901, which stated that once a person was infected there were only two ways to remove materies morbi from the body, "by the knife ... or by the natural defences of the organism aided by rest, careful dieting, and in some cases drugs, including such medicaments as the antitoxins". ${ }^{44}$ This relegation of antitoxins to usage "in some cases", might be read as clinicians hitting back at the scientific modernizers and their novel theories and practices. ${ }^{95}$ Thus, Howse cited Listerism not as a wonder of the age, but as an example of where surgeons had been led "to conclude too much from a single instance", such that "rapid changes ... in the treatment of wounds ... have chased each other like cloud-shadows across our surgical stage". ${ }^{96}$ There was also more reflection on what had been "lost" in the past 100 years, and the momentum towards change for.change's sake. Frederick Treves pondered whether operative surgeons had passed "from the policy of doing too little to the policy of doing too much".$^{97} \mathrm{He}$ also bemoaned the way that instruments had replaced surgical insight, which he characterized as "that refined sensibility, that critical perception, that inestimable cunning, which lies in the surgeon's touch". ${ }^{88}$ The questioning of scientific medicine seems to have encouraged certain individuals to settle old scores. It was at the BMA in the summer of 1899 that George Wilson made his famous attack on bacteriology and vivisection, while at the same meeting Richard Douglas Powell, a Tory and old-style clinician, even revived the notion of spontaneous generation, expounding his belief in "a mephitic laboratory beyond our special control, yielding organisms ever ready to attack the unwary and those whose vitality is depressed". 99

The international context of histories of nineteenth-century science and medicine was exemplified by Michael Foster's presidential address to the BAAS in August

\footnotetext{
${ }^{91}$ Practitioner, 1897, 59: 232. Foster was speaking at the BMA annual meeting in Montreal.

${ }^{92}$ Roberts, op. cit., note 81 above, pp. 999. M Worboys, 'The sanatorium treatment of consumption in Britain, 1895-1914', in J V Pickstone (ed.), Medical innovations in historical perspective, Basingstoke, Macmillan, 1992, pp. 47-71.

${ }^{93}$ Cf. G M Carfrae, 'The drift of modern medicine', New Rev., 1896, 15: 182-92.

${ }^{94}$ Lancet, 1901, i: 41.

${ }^{95}$ Speaking of remedies, Roberts hoped "that in our love of the new we will not entirely throw
}

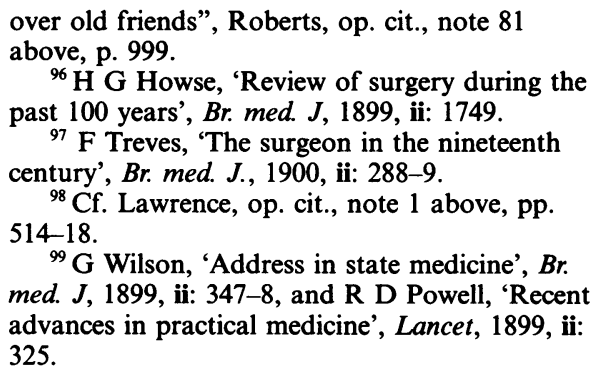

${ }^{97} \mathrm{~F}$ Treves, 'The surgeon in the nineteenth century', Br. med. J., 1900, ii: 288-9.

${ }^{98} \mathrm{Cf}$. Lawrence, op. cit., note 1 above, pp. 514-18.

${ }^{99} \mathrm{G}$ Wilson, 'Address in state medicine', $\mathrm{Br}$. med. J, 1899, ii: 347-8, and R D Powell, 'Recent advances in practical medicine', Lancet, 1899, ii: 325. 


\section{British Medicine and its Past}

1899. ${ }^{100}$ His historical sense of the development of science was typically positivist and sexist; he approvingly quoted Crookes's metaphors of "barriers ... withdrawn" and "veil after veil [being] lifted" as knowledge became more exact and less hindered by metaphysics. He added that this had been aided by the growing "brotherhood of science" which had been created both by common purposes and assumptions, and also by the improvements in transportation and communications. Indeed, the century opened with one of the largest ever international medical congresses in Paris, events that were now regularly attended by doctors from the Americas, Asia and Africa. More generally, the progress of medicine was linked to the advance of civilization, both material and intellectual. Economic growth, technological changes, the reform of manners, and the democratization of institutions and politics, were all said to have broadened the opportunities for the improvement of health and created both the resources and the demand for advances in medicine and surgery.

For the most part, the "progress of medicine" was presented as having been the past, with few doctors looking forward and speculating on the shape of things in the twentieth century or beyond. One certainty was the transfer and application of current medical science and institutions to undeveloped, "less civilized" parts of the world, indeed, there was still work to be done diffusing current best practice to all social groups at home. This led some doctors to be optimistic about a continuing decline in mortality rates, say from the 1900 level of 18 per 1000 population (having been 22 per 1000 in the 1840 s) to perhaps 10 or 12 per 1000 in the twentieth century. (The figure for $c .2000$ in Britain was 5-6 per 1000.) The research wing of the profession expected more vaccines and antisera to be developed, while public health was expected to be shaped by the dissemination of medically-based advice on hygiene and lifestyle, in other words, the beginnings of the medicalization of everyday life. ${ }^{101}$ George Eastes, in an address to the South-Eastern Branch of the BMA, worried about the impact of improvements on the rank and file of the profession. He bemoaned the fact that overcrowding amongst general practitioners was being made worse by the loss of work and income that followed the decline in infectious diseases, the lack of complications in wound healing, and the loss of difficult cases to hospitals or specialists.

Eugenic concerns had been aired for many years and William Ewart, in his Harveian Lectures in 1898, typified these when he remarked on the profession's unwillingness to confront the question of "the soundness of future generations and the exclusion of heritable diseases". ${ }^{102}$ However, the profile given to these matters owed more to the fears about physical degeneration linked to the South African War than to widespread worries about the eugenic status of the population. Indeed, notions of degeneration were not always hereditarian. In 1893, the physician Arthur

${ }^{100}$ M Foster, 'Presidential address', Report of the Sixty-Ninth Meeting of the BAAS, Dover, September 1899, London, J Murray, 1900, pp. 3-23.

${ }^{101}$ Lancet, 1899 , ii: 376.

${ }^{102} \mathrm{~W}$ Ewart, 'On disease and its treatment, and the profession of medicine in the year 1899',
Br. med. J., 1898, ii: 1740. In 1897, H Baptist Crofts noted that state medicine had only developed its prophylactic or negative side, and that the positive function of "cultivating the best and eradicating the worst physical tendencies of the race" had yet to be developed. Crofts, op. cit., note 52 above, pp. 572-4. 


\section{Michael Worboys}

Symons Eccles had speculated on physiological decline, specifically on how city life and labour-saving equipment had produced "muscular disuse and flaccidity" with consequent metabolic and mental effects. ${ }^{103}$ There was some eugenic speculation, though this was dominated by the work of Benjamin Kidd and G A Reid, rather than that of Francis Galton, whose work only began to receive widespread public and professional attention from the end of $1901 . .^{104}$

\section{Victoria's Death}

Queen Victoria died on 22 January 1901. Her worsening health had been common knowledge for months, but she deteriorated quickly and her death caught those around her unprepared. The funeral was not a grand affair and the country soon returned to normal after a quite brief period of official mourning. The medical press also dealt with the Queen's death briefly as, like other newspapers and periodicals, they carried black-bordered announcements and obituaries. ${ }^{105}$ Her death was marked with messages of condolence to the royal family from specialist and regional medical societies, but none of the specialist journals marked the event with retrospectives. Victoria's obituary notices in medical journals combined three themes: (i) the advance of civilization in her reign, especially economic growth, social reform and imperial expansion; (ii) the many "fruitful discoveries" and "great improvements" in medicine and surgery since 1837; and (iii) the Queen's personal attitude to medicine. Again there was said to be no need for further reviews of the Victorian era, so reflections concentrated on the Queen's personal relations with the profession, perhaps reflecting the style of the funeral and mourning. Victoria's attitude to the profession was traced back to her very early years and her parents' decision in 1819 to have the young princess vaccinated against smallpox - the first member of the royal family to undergo the procedure. On her accession and through her years with Albert, it was said that she had close relations with her personal physicians and surgeons, not because she had particularly poor health, rather the reverse-her robust health and long life was due to the quality of preventive advice she received. The point being made was that even the head of state had obediently followed medical advice. Her interest in hospitals was noted, as was her compassion for the sick and injured. More specifically, she was seen to have supported the two great innovations of her era: she had taken chloroform anaesthesia in 1853 when its use was still controversial and had submitted to minor surgery with antiseptics by Lister in the early 1870 s when the majority of surgeons still doubted the value of his methods. ${ }^{106}$ However, the Queen had never been that enamoured by Lister's use of, and support for, vivisection.

As far as the medical profession was concerned it was- "The Queen is dead, long live the King"-for they had high hopes of Edward VII. He came to the throne with a

\footnotetext{
${ }^{103}$ A Symons Eccles, 'Fin de siècle medicine', National Rev., 1893, 21: 788.

${ }^{104} \mathrm{H} \mathrm{G}$ Wells recommended the writings of Kidd and Reid as examples of serious futurology. B Kidd, Social evolution, London, Macmillan, 1895; G A Reid, The present evolution of man, London, Chapman \& Hall, 1896; Wells, op. cit.,
}

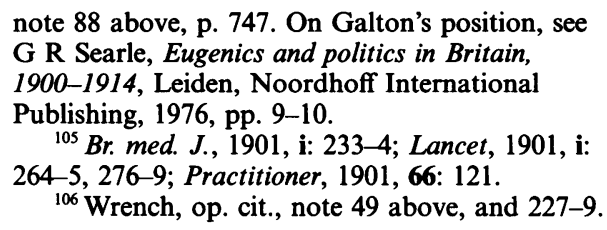




\section{British Medicine and its Past}

record of support for hospitals and as a Fellow of both Royal Colleges. He had a record of interest in sanitary matters, having been Chairman of the Royal Commission on the Housing of the Poor, and was the patron of the Prince of Wales Fund and the National Association for the Prevention of Consumption. The King showed that he intended to continue in this vein, when in the summer of 1901 he agreed to become the patron of the British Medical Association. The death of his mother was also taken as an opportunity to revive the troubled hospital scheme as the King's Fund. This was again organized by Burdett, whose efforts in the coronation year saw over $£ 600,000$ raised; though most came from one large donation rather than wide public support for, and giving to, hospitals. ${ }^{107}$ The King continued to be a godsend to medicine during the coronation year. The ceremony, planned for the end of June, was delayed two months due to his developing a serious illness. He was diagnosed as suffering from a possible appendicitis and was operated on by Frederick Treves, after advice from Lister. Treves found an appendicular abscess and cured it by drainage rather than appendectomy. Needless to say, this was presented as a lifesaving operation, a remarkable demonstration of the power of modern surgery, and another medically inspired deliverance, like his recovery from typhoid fever in $1871 .^{108}$

\section{Conclusion}

A strong case can be made that the character of the medical events discussed here followed the wider pattern of commemorations and ruminations rather than the specific concerns of the profession and its leaders. According to this view, the Golden Jubilee was very much a domestic, English event, and the Diamond Jubilee thoroughly imperial and celebratory. Recognition, let alone celebration, of the turn of the century in 1899 and 1900 was sporadic and there was greater ambivalence about "progress", whilst Victoria's death was regarded as a personal matter. Certainly, doctors and supporters of medical institutions tried to use the royal events of 1887, 1897 and 1901 to further their own interests. However, they had mixed results in public appeals for donations to hospitals, reflecting the enduring problems of charities at the end of the century, as well as the continuing ambivalence the public felt about medicine, hospitals and the royal family. All institutions were seeking a more positive image and it is significant that they saw mutual benefit in the association that created, in Frank Prochaska's phrase, the modern "welfare monarchy". The fact that medicine did not receive the number and rank of honours its leaders thought it deserved throughout this period was blamed on politicians, not on the royal connection. However, the presence of the senior members of the two other old professions, judges and archbishops, sitting as of right in the House of Lords was a constant reminder of medicine's continuing lack of official recognition and absence from the corridors of power.

Overall, élite doctors and publicists offered rich and diverse characterizations of their profession, stressing humanitarian, social and charitable works, as well as

\footnotetext{
${ }^{107}$ Prochaska, Philanthropy, op. cit., note 43 above, passim.
}

${ }^{108}$ Lancet, 1902 , ii: $28-30,448-9$. 


\section{Michael Worboys}

medical science, preventive medicine and clinical interventions. In exploiting and responding to each event, the medical profession's senior figures, leaders, and spindoctors were adept at adjusting the form and content of their rhetoric to audiences and the specificities of time and place. The histories created for each event showed clear evidence of the immediate present in the past. In 1887, medical scientists remained in the background as the initiative was seized by the hospital lobby who portrayed individual doctors as sympathetic carers, with a service ethos. Little was said about the profession as a whole and its organizations; while medical science was said to have refined the "art" of medicine, making it safer and more humane. In contrast, 1897 saw a great celebration of medical science, especially laboratory research and the importation of techniques from the physical sciences. Optimism was fed by the impact of X-rays, antitoxic sera, the new pharmacology, replacement therapy, and operative surgery. In 1899 and 1900 there was a subtle change in tone. While the dominant theme remained that of medical progress, there was more willingness to air problems. The improvement in public health was thought to be diminishing the demands for health care, yet there were also emerging worries about physical and mental degeneration. More was expected from the laboratory, but equally there was a growing belief in the importance of the "personal factor" in disease, both inherited and acquired characteristics, as well as behavioural and environmental determinants. At her death, Victoria's longevity was explained largely by her lifestyle. The King's recovery from his operation was explained as being due as much to the constitutional strength that came from his pursuit of outdoor sports, as to Treves's expertise. The changes between the five commemorative events demonstrate the value of comparative studies and caution against focusing on single events in developing a cultural history of medicine.

The histories of medicine created for all five moments were based on the positivist philosophy of science, which chronicled those "great men" who had made factual "contributions" to the present body of knowledge and practice. While there was no shortage of discoveries and innovations to record, two stood out in every account and by the end of the 1890s were enshrined as icons of the era-anaesthesia and antisepsis. Everyone could agree on their significance because both were claimed by the various parties fighting for medicine's identity and ethos. Those doctors who saw medicine as an "art" argued that these innovations were triumphs of clinical methods, developed in practice by clinicians; they were procedures that made medicine more humane by reducing suffering and hastening healing, benefits enjoyed by Victoria and her eldest son. For those who promoted medicine as science, both innovations were based on basic science, chemistry and biology respectively, and had been refined in the laboratory by experiment. They now allowed surgeons to intervene to remove the causes of disease, and had revolutionized surgical and medical practice and the sciences of neurology and pathology. Indeed, it was around these innovations that new speculation on the future of medicine began to develop, but not until the late 1900 s. ${ }^{109}$

${ }^{109}$ A E Wright, 'The future of medicine', $\mathrm{Br}$. med. J., 1907, i: 333-4. 